\title{
Frontiers and Prospects for Recycling Waste Electrical and Electronic Equipment (WEEE) in Nigeria
}

\author{
${ }^{1 *}$ OKORHI, OJ; ${ }^{2}$ OKEREKA, EE; ${ }^{3}$ AKHIMIE, CO; ${ }^{4}$ ENEKWENCHI, KK \\ ${ }^{1}$ Institute of Engineering, Technology, and Innovation Management (METI), University of Port Harcourt, Rivers/Science Policy and \\ Innovation Studies (SPIS), National Centre for Technology Management (NACETEM), South East Zonal Office, Enugu, Nigeria. \\ *Email: johnsonokorhi@gmail.com \\ ${ }^{2}$ Materials and Energy Technology (MET) Department, Projects Development Institute (PRODA), Enugu, Nigeria. \\ Email: exotiknuella@yahoo.com \\ ${ }^{3}$ Science Policy and Innovation Studies (SPIS), National Centre for Technology Management (NACETEM), \\ South East Zonal Office, Enugu, Nigeria.Email: clemakom@yahoo.com \\ ${ }^{4}$ Science Policy and Innovation Studies (SPIS), National Centre for Technology Management (NACETEM), \\ South East Zonal Office, Enugu, Nigeria. Email: Enekwenchikingsley001@gmail.com
}

\begin{abstract}
This paper reviews the frontlines and projections for the recycling of waste electrical and electronic equipment (WEEE) in Nigeria. The paper identified the sources of WEEE, showed chemical characterization of some WEEE components and presented measures to minimize these wastes through recycling opportunities. It highlighted the perspective of WEEE trails and key reasons attributed to its generation. The potentials for innovation in WEEE recycling were further discussed in line with elements of sustainability and policy directions were proffered.
\end{abstract}

DOlhttps://dx.doi.org/10.4314/jasem.v21i7.30

Copyright: Copyright (C) 2017 Akomah and Abu. This is an open access article distributed under the Creative Commons Attribution License (CCL), which permits unrestricted use, distribution, and reproduction in any medium, provided the original work is properly cited

Dates: Received 08 December 2017; received in revised form 24 December 2017; accepted 31 December 2017

Keywords: Waste electrical and electronic equipment (WEEE); e-waste; Recycling

Health and environmental issues resulting from indiscriminate dumping of hazardous waste electrical and electronic equipment (WEEE or e-waste) are universally acknowledged problems. This is a fallout from the unrestrained trafficking of such wastes from industrialized nations to developing ones in Africa, South America and Asia (Okorhi, Omotor, Aderemi and Abang, 2017). E-waste are noted to be a close avenue for harmful wastes penetrating into the environment and affecting human health. As a consequence, starting in the late 1980 s there arose, in many developed countries, strong stand on waste management issues with the application of stringent environmental guidelines, leading to an unprecedented rise in the cost implication of disposing harmful wastes, and frantic efforts by "toxic traders" to move hazardous wastes into developing countries which had relaxed environmental laws (GFMECD, 1995; Alo, 2009). In the search for a cut-price and faster ways to get rid of the mounting problem these illicit traders started shipping hazardous wastes to developing nations with less stringent laws on harmful wastes (Osibanjo and Nnorom, 2007, 2008; Ayodeji, 2011; The Guardian, 2012; Vanguard, 2013). However, with subsequent awareness creation, developing countries started keying into international treaties addressing harms and challenges presented by perilous wastes (Bamako 1991; StEP, 2011; NESREA, 2011b; Basel Convention, 2011a). A worldwide indignation following these actions gave rise to the formulation and approval of policies and guidelines at a convention in Basel, Switzerland - popularly referred to as the "Basel Convention" - (European Union, 2006; Basel Convention, 2011b). Hereafter, many governments started working assiduously to develop policies, guidelines and legislations to cater for managing e-waste (NESREA, 2011a, NESREA, 2011b; StEP, 2011). The Basel Convention on the Control of Transboundary Movements of Hazardous Wastes and their Disposal of 1989, is acknowledged to be one of the most significant existing and inclusive global treaty addressing the WEEE problem. It's a common observation in Nigeria to find the management strategies employed to special (hazardous) waste like WEEE as the same with general solid waste management practices in the collection, intermediate storage, transporting and final disposal (Okorhi et al., 2017). The use of obsolete operational legislations such the Public Health Law (Cap 134) of 1957 on Sanitation and Housing still remain part of the policy framework 
consulted by sanitation managers at the grassroots in the disposal of solid wastes (including e-waste) (Okorhi, 2015). Therefore, the recycling of e-waste is a key strategy for reducing "stockpiled" waste streams, minimizing the consumption of natural resources as well as improving energy usage.

There arose global concerns and push for answers to the rising volume of wastes from electrical and electronic equipment (EEE), the transboundary trafficking from developed to developing nations, as well as its relative negative impacts on human health and the environment (Europe Union, 2006; BCCCNigeria and Empa, 2011). It is reported that in 2008, nearly 180 million tonnes of End-of-Life (E.o.L) EEE were intended for landfilling in Australia. And by the year ending 2009, the country's authority established a National Waste Policy stipulating a ten year idea for material recovery and waste handling and control with a deliberate producer-led (and government support) initiative for reprocessing obsolete home appliances and computer wares (Davis and Herat, 2008; TEC, 2008; Garrett, 2009). Ongodo and William (2011) had suggested that there are four globally acclaimed issues which makes e-waste an important waste stream, vis-a-vis: global quantities of e-waste; the resource effects; impending health and environmental effects; as well as ethical concerns. Although there appear to be insufficient statistics, but estimations put the annually globally volume of generated e-waste to be between 20-50 million tonnes (Ketai et al., 2008; Basel Convention, 2011a; Ongodo and William, 2011). Secondly, the ease to getting vital production materials used in the manufacture of EEE is progressively attracting concern as the global reserves is fast decline and becoming more expensive. Another is that WEEE has over one thousand diverse constituents. Many of these constitutes are highly toxicants. They have hypothetically gravely environmental and health effects when carelessly thrown away (Agency for Toxic Substances and Disease Registry, ATSDR, 2017). Lastly, the use of juvenile for work in the informal WEEE sector in many countries of Africa and Middle East, as well as the criminal trafficking of e-waste from developed to developing nations which required frontier facilities to collect, handle, process and dispose of such category of wastes is of great concern to many (Osibanjo and Nnorom, 2008; Alo, 2009; BCCC-Nigeria and Empa, 2011; Ongodo and William, 2011; Vanguard, 2013). There has been substantial media reports on transboundary movement of WEEE in Nigeria (Puckett, Byster, Westervelt, Gutierrez, Davis, Hussain, and Dutta, 2003). These reports projected that about five hundred containers of used electrical and electronic equipment (UEEE) are been imported on a daily basis into the Ports of Lagos, Nigeria (Oresanya, 2011; Okorhi, Amadi-Echendu, Aderemi and Otejere, 2015a). It was also noted that in an inspection of 176 containers loaded with UEEE for categories 2-4 conducted within the months of March and July, $2010,60 \%$ of the consignments came in from the UK alone, over $75 \%$ of the entire containers came from seaports in Europe, about $15 \%$ from countries of Asia, while 5\% mainly from the seaport of Morocco and another $5 \%$ from Canada and United State of America (Ayodeji, 2011; BCCC-Nigeria and Empa, 2011). Today, many African nations are still held back with respect to legislating appropriate regulations to manage e-waste. For instance in Nigeria, WEEE is commonly managed via the municipal waste management schemes (Enugu State Waste Management Authority (ESWAMA), 2004; Okorhi et al., 2012; Okorhi, 2017). However, when the need arises, enforcement agencies often cites the stipulations of the Harmful Waste (Special Criminal Provisions) Act Cap H1 LFN 2004 for the management of WEEE and other related dangerous wastes. The National Environmental Standards and Regulations Enforcement Agency (NESREA), mandated to enforce all environmental legislations together with the checking and regulating e-waste trafficking, of late returned a WEEE carrying ship back to the United Kingdom (NESREA, 2007; Vanguard, 2013). This vessel was loaded with harmful consignments labelled as UEEE or near E.o.L EEE purported for the Nigeria environment. Before the year 2011, the same government agency had intercepted and detained 5 foreign ocean carriers loaded with WEEE designated for Nigeria (Okorhi et al., 2015a). The aim of this paper is to review frontlines and projections for the recycling of waste electrical and electronic equipment (WEEE) in Nigeria.

\section{MATERIALS AND METHODS}

The key methodical concept adopted for this study is based on reviews from published literature on harmful wastes from EEE, characteristics of chemical composition of WEEE, and the types and effects of pollution from WEEE on components of the environment. The paper elicited data from secondary sources including textbooks, journals, conference articles, newspapers, policy frameworks, guidelines, by-laws and regulations. It then discussed frontiers for WEEE reprocessing and the sustainability benchmarks for evaluating and adopting technologies for e-waste recycling, some innovative e-waste recycling technologies that could be adopted by recycling firms and manufacturers, as well as the market potential for e-waste recycling at firm level. 


\section{RESULTS AND DISCUSSION}

Electrical and Electronic Equipment are recognized to contain more than one thousand diverse materials, many of which are classified to be of extreme hazards (Ongondo and Williams, 2011). These items can be classified into individual components and their basic constitutes. Table 1 shows such representation. Besides, the table gave a simplified breakdown of the frequently found toxic substances in e-waste.

Table 1: Representation of some WEEE Components and Basic Constitutes

\begin{tabular}{|c|c|}
\hline COMPONENTS & KEY CONSTITUENTS \\
\hline Printed circuit boards & Lead and chromium \\
\hline Cathode ray tubes (CRTs) & Lead oxide and Cadmium \\
\hline Switches and flat screen monitors & Mercury \\
\hline Computer batteries & Cadmium \\
\hline Capacitors and transformers & Poly Chlorinated, Bi-phenyls (PCB) \\
\hline EEE Plastic Casing & Brominated Flame, Retardants in casings and cables -PBBs, PBDEs \\
\hline Electric cable insulation/coating & Poly Vinyl Chloride (PVC); Dioxin emissions from burning to liberate copper \\
\hline Radio, amplifier and Stereo ICs & Lead and chromium; Brominated Flame Retardants in casings and cables \\
\hline Batteries & Cadmium, lead \\
\hline Capacitors and transformers & Poly Chlorinated, Bi-phenyls (PCB) \\
\hline \multicolumn{2}{|c|}{ A Range of Frequently Found Toxic Substances in WEEE } \\
\hline Substance & Occurrence in e-waste \\
\hline \multicolumn{2}{|l|}{ Halogenated compounds: } \\
\hline - PCB (polychlorinated biphenyls) & Condensers, Transformers \\
\hline - TBBA (tetrabromo-bisphenol-A) & Fire retardants for plastics (thermoplastic components, cable insulation) \\
\hline - PBB (polybrominated biphenyls) & TBBA is presently the most widely used flame retardant in printed wiring boards \\
\hline - PBDE (polybrominated diphenyl ethers) & and casings. \\
\hline - Chlorofluorocarbon (CFC) & $\begin{array}{l}\text { Cooling unit, Insulation foam. Examples founded in air-conditioners, refrigerators } \\
\text { etc. }\end{array}$ \\
\hline - PVC (polyvinyl chloride) & Cable insulation - Armored cables and other insulated cables \\
\hline \multicolumn{2}{|l|}{ Heavy metals and other metals: } \\
\hline - Arsenic & Small quantities in the form of gallium arsenide within light emitting diodes \\
\hline - Barium & Getters in CRT \\
\hline - Beryllium & Power supply boxes which contain silicon controlled rectifiers and $\mathrm{x}$-ray lenses \\
\hline - Cadmium & $\begin{array}{l}\text { Rechargeable NiCd-batteries, fluorescent layer (CRT screens), printer inks and } \\
\text { toners, photocopying-machines (printer drums) }\end{array}$ \\
\hline - Chromium VI & Data tapes, floppy-disks \\
\hline - Lead & CRT screens, batteries, printed wiring boards \\
\hline - Lithium & Li-batteries \\
\hline - Mercury & $\begin{array}{l}\text { Fluorescent lamps that provide backlighting in LCDs, in some alkaline batteries and } \\
\text { mercury wetted switches }\end{array}$ \\
\hline - Nickel & Rechargeable NiCd-batteries or NiMH-batteries, electron gun in CRT \\
\hline - Rare Earth elements (Yttrium, & Fluorescent layer (CRT-screen) \\
\hline \multicolumn{2}{|l|}{ Europium) } \\
\hline - Selenium & Older photocopying-machines (photo drums) \\
\hline - Zinc sulphide & Interior of CRT screens, mixed with rare earth metals \\
\hline \multicolumn{2}{|r|}{ 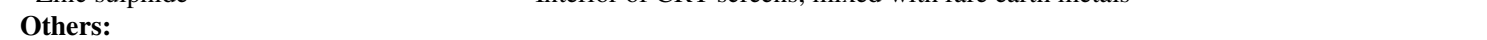 } \\
\hline - Toner Dust & Toner cartridges for laser printers / copiers \\
\hline \multicolumn{2}{|l|}{ Radio-active substances } \\
\hline - Americium & Medical equipment, fire detectors, active sensing element in smoke detectors \\
\hline
\end{tabular}

At the global stage, there is a legislation restricting the usage of harmful materials in the manufacturing of EEE. This is commonly cited as the "Restriction of Hazardous Substances Directive (RoHS Directive)" (European Union, 2006; Onyejekwe, 2009). The European Union approved it by legislation in the year 2003 but its full implementation commenced in 2006. In particular, this directive restricted the application of 6 substances considered to be hazardous in the manufacturing of e-devices (European Union, 2006; NESREA, 2009; Basel Convention, 2011b). These are substances of heavy metals like and complex compounds. In furtherance to this, examples and the chemical characterization for some of these substances is discussed in Table 2.

Health and environmental problems linked with ewastes are reflected on air, land and water (Okorhi, Amadi-Echendu and Aderemi, 2015b). The impacts on air commonly arises from the burning of WEEE and expelling of gaseous components thereby introducing associated contaminants/pollutants as well as effecting the quality of air in the ecosystem. On land, the impacts of persistent organic pollutants reflect in the coarseness and colouration of soil and the worthiness of land for farming purposes. While such contaminants in water appears as introduced 
solid sediments, with heavy metals trace altering water taste and the standards of acidity or alkalinity of water which is inappropriate for direct consumption by humans, animal and plants. Tables 3 , 4 and 5 gives detailed representation of e-waste constituents and their relative associated effects.

Table 2: Chemical Characterization of WEEE Components (Adapted from EMPA, 2009)

\begin{tabular}{|c|c|}
\hline WEEE Constitutes & Features \\
\hline Arsenic & $\begin{array}{l}\text { Arsenic is a poisonous metallic element which is present in dust and soluble substances. Chronic exposure to } \\
\text { arsenic can lead to various diseases of the skin and decrease nerve conduction velocity. Chronic exposure to arsenic } \\
\text { can also cause lung cancer which could be fatal. }\end{array}$ \\
\hline Barium & $\begin{array}{l}\text { Barium is a metallic element that is used in sparkplugs, fluorescent lamps and "getters" in vacuum tubes. Being } \\
\text { highly unstable in the pure form, it forms poisonous oxides when in contact with air. Short-term exposure to barium } \\
\text { could lead to brain swelling, muscle weakness, damage to the heart, liver and spleen. Animal studies reveal } \\
\text { increased blood pressure and changes in the heart from ingesting barium over a long period of time. The long-term } \\
\text { effects of chronic barium exposure to human beings are still not known due to lack of data on the effects. }\end{array}$ \\
\hline Beryllium & $\begin{array}{l}\text { Beryllium has recently been classified as a human carcinogen because exposure to it can cause lung cancer. The } \\
\text { primary health concern is inhalation of beryllium dust, fume or mist. Workers who are constantly exposed to } \\
\text { beryllium, even in small amounts, and who become sensitised to it can develop what is known as Chronic } \\
\text { Beryllium Disease (beryllicosis), a disease which primarily affects the lungs. Exposure to beryllium also causes a } \\
\text { form of skin disease that is characterised by poor wound healing and wart-like bumps. Studies have shown that } \\
\text { people can still develop beryllium diseases even many years following the last exposure. }\end{array}$ \\
\hline Brominated & The three main types of BFRS used in electronic and electrical appliances are Polybrominated biphenyl (PBB), \\
\hline Retardants (BFRs) & $\begin{array}{l}\text { Polybrominated diphenyl ether (PBDE) and Tetrabromobisphenol - A (TBBPA). Flame retardants make materials, } \\
\text { especially plastics and textiles, more flame resistant. They have been found in indoor dust and air through migration } \\
\text { and evaporation from plastics. Combustion of halogenated case material and printed wiring boards at lower } \\
\text { temperatures releases toxic emissions including dioxins which can lead to severe hormonal disorders. Major } \\
\text { electrical and electronics manufacturers have begun to phase out brominated flame retardants because of their } \\
\text { toxicity. }\end{array}$ \\
\hline Cadmium & $\begin{array}{l}\text { Cadmium components may have serious impacts on the kidneys. Cadmium is adsorbed through respiration but is } \\
\text { also taken up with food. Due to the long half-life in the body, cadmium can easily be accumulated in amounts that } \\
\text { cause symptoms of poisoning. Cadmium shows a danger of cumulative effects in the environment due to its acute } \\
\text { and chronic toxicity. Acute exposure to cadmium fumes causes flu-like symptoms of weakness, fever, headache, } \\
\text { chills, sweating and muscular pain. The primary health risks of long term exposure are lung cancer and kidney } \\
\text { damage. Cadmium also is believed to cause pulmonary emphysema and bone disease (osteomalacia and } \\
\text { osteoporosis). }\end{array}$ \\
\hline $\begin{array}{l}\text { CFCs } \\
\text { (Chlorofluorocarbons) }\end{array}$ & $\begin{array}{l}\text { Chlorofluorocarbons are compounds composed of carbon, fluorine, chlorine, and sometimes hydrogen. Used } \\
\text { mainly in cooling units and insulation foam, they have been phased out because when released into the atmosphere, } \\
\text { they accumulate in the stratosphere and have a deleterious effect on the ozone layer. This results in increased } \\
\text { incidence of skin cancer in humans and in genetic damage in many organisms. }\end{array}$ \\
\hline Chromium & $\begin{array}{l}\text { Chromium and its oxides are widely used because of their high conductivity and anti-corrosive properties. While } \\
\text { some forms of chromium are non-toxic, Chromium (VI) is easily absorbed in the human body and can produce } \\
\text { various toxic effects within cells. Most chromium (VI) compounds are irritating to eyes, skin and mucous } \\
\text { membranes. Chronic exposure to chromium (VI) compounds can cause permanent eye injury, unless properly } \\
\text { treated. Chromium VI may also cause DNA damage. }\end{array}$ \\
\hline Dioxins & $\begin{array}{l}\text { Dioxins and furans are a family of chemicals comprising } 75 \text { different types of dioxin compounds and } 135 \text { related } \\
\text { compounds known as furans. Dioxins is taken to mean the family of compounds comprising polychlorinated } \\
\text { dibenzo-p-dioxins (PCDDs) and polychlorinated dibenzofurans (PCDFs). Dioxins have never been intentionally } \\
\text { manufactured, but form as unwanted by-products in the manufacture of substances like some pesticides as well as } \\
\text { during combustion. Dioxins are known to be highly toxic to animals and humans because they bio-accumulate in } \\
\text { the body and can lead to malformations of the foetus, decreased reproduction and growth rates and cause } \\
\text { impairment of the immune system among other things. The best-known and most toxic dioxin is } 2,3,7,8- \\
\text { tetrachlorodibenzo-p-dioxin (TCDD). }\end{array}$ \\
\hline Lead & $\begin{array}{l}\text { Lead is the fifth most widely used metal after iron, aluminium, copper and zinc. It is commonly used in the } \\
\text { electrical and electronics industry in solder, lead-acid batteries, electronic components, cable sheathing, in the glass } \\
\text { of CRTs etc. Short-term exposure to high levels of lead can cause vomiting, diarrhea, convulsions, coma or even } \\
\text { death. Other symptoms are appetite loss, abdominal pain, constipation, fatigue, sleeplessness, irritability and } \\
\text { headache. Continued excessive exposure, as in an industrial setting, can affect the kidneys. It is particularly } \\
\text { dangerous for young children because it can damage nervous connections and cause blood and brain disorders. }\end{array}$ \\
\hline Mercury & $\begin{array}{l}\text { Mercury is one of the most toxic yet widely used metals in the production of electrical and electronic applications. } \\
\text { It is a toxic heavy metal that bioaccumulates causing brain and liver damage if ingested or inhaled. In electronics } \\
\text { and electrical appliances, mercury is highly concentrated in batteries, some switches and thermostats, and } \\
\text { fluorescent lamps. }\end{array}$ \\
\hline $\begin{array}{l}\text { Polychlorinated } \\
\text { biphenyls (PCBs) }\end{array}$ & $\begin{array}{l}\text { Polychlorinated biphenyls (PCBs) are a class of organic compounds use in a variety of applications, including } \\
\text { dielectric fluids for capacitors and transformers, heat transfer fluids and as additives in adhesives and plastics. } \\
\text { PCBs have been shown to cause cancer in animals. PCBs have also been shown to cause a number of serious non- } \\
\text { cancer health effects in animals, including effects on the immune system, reproductive system, nervous system, } \\
\text { endocrine system and other health effects. PCBs are persistent contaminants in the environment. Due to the high } \\
\text { lipid solubility and slow metabolism rate of these chemicals, PCBs accumulate in the fat-rich tissues of almost all } \\
\text { organisms (bioaccumulation). The use of PCBs is prohibited in Organization for Economic Cooperation and } \\
\text { Development (OECD) countries, however, due to its wide use in the past, it still can be found in waste electrical }\end{array}$ \\
\hline
\end{tabular}




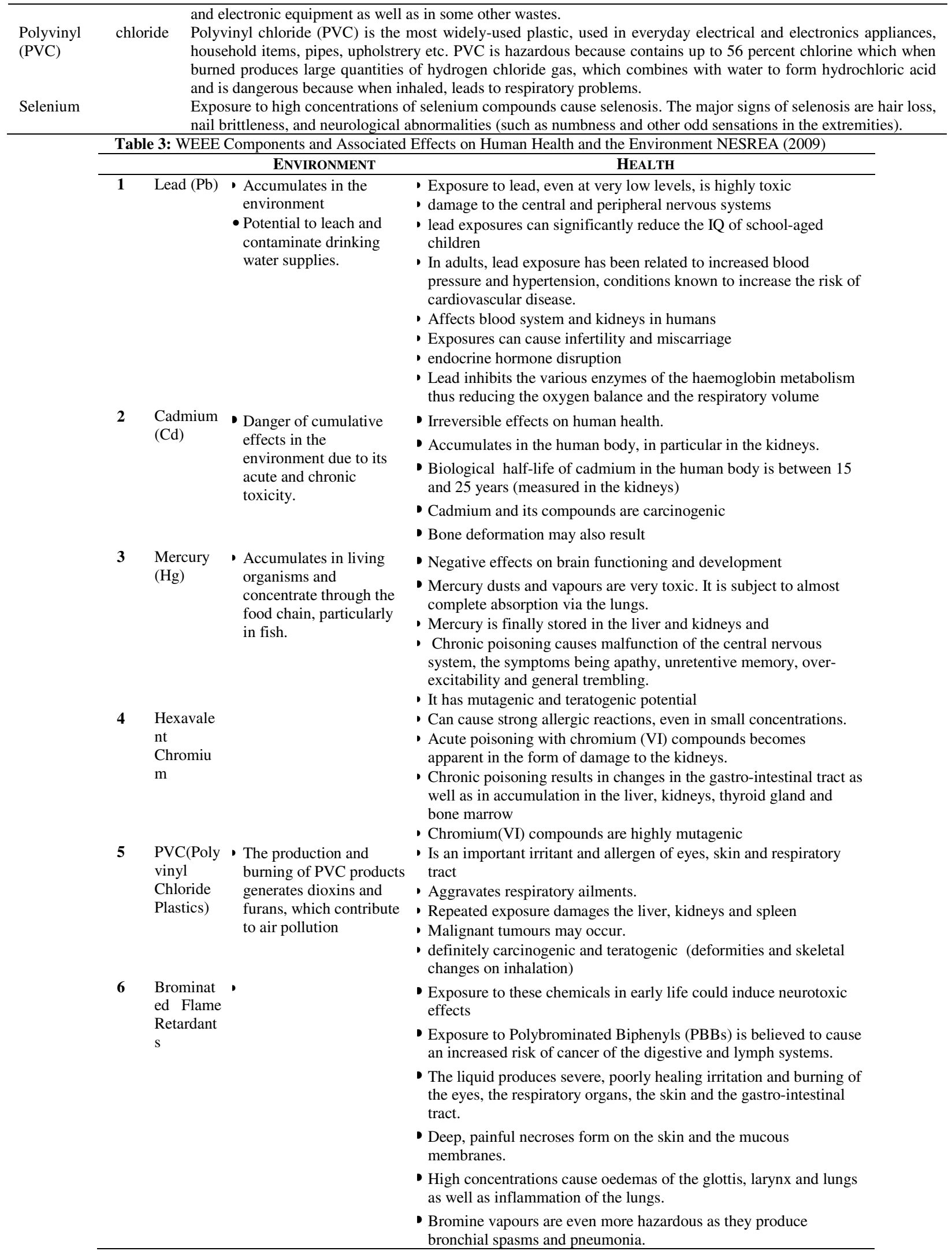


Complete industrialization of Africa could be achieved by sustainable innovation and awareness creation of its innovative potentials. Until lately, policy frameworks for e-waste management are simply focused on the Control of Transboundary
Movements of Hazardous Wastes and their Disposal, as well as Extended Producer Responsibility programmes for E.o.L EEE (Okorhi, 2015).

Table 4: Tabular Representation of the WEEE Components and Associated Impacts on Air, Water and Land NESREA (2009)

\begin{tabular}{|c|c|c|c|c|}
\hline \multirow{2}{*}{$\mathbf{S} / \mathbf{N}$} & \multirow{2}{*}{ COMPONENT } & \multicolumn{3}{|c|}{ ENVIRONMENT } \\
\hline & & AIR & WATER & LAND \\
\hline 1 & Lead $(\mathrm{Pb})$ & $\begin{array}{l}\text { Lead compounds may be } \\
\text { transported over a } \\
\text { considerable distance } \\
\text { depending on the speed and } \\
\text { direction of the wind as well } \\
\text { as precipitation and humidity. } \\
\text { However, most of the lead in } \\
\text { the atmosphere directly } \\
\text { sediments or is removed by } \\
\text { precipitation. } \\
\text { Lead bonds to small dust } \\
\text { particles in the air which in } \\
\text { turn are deposited on } \\
\text { vegetation and soil }\end{array}$ & $\begin{array}{l}\text { - Surface water forms an accumulation sink for } \\
\text { lead compounds. } \\
\text { - Insoluble lead compounds sink and are adsorbed } \\
\text { in the sediment or accumulate on suspended } \\
\text { matter (in particular the clay fraction). } \\
\text { - Aquatic plants likewise accumulate lead. } \\
\text { - The biochemical oxidation of organic substances } \\
\text { is inhibited at lead concentrations above } 0.1 \mathrm{mg} / 1 \\
\text { - fauna is depleted by concentrations above } 0.2 \\
\text { mg/l } \\
\text { - Groundwater is adversely affected by soluble } \\
\text { lead compounds (e.g. lead chloride, nitrate) }\end{array}$ & $\begin{array}{l}\text { - The absorption rate depends on } \\
\text { the properties of the soil. There } \\
\text { is a considerable affinity with } \\
\text { humic substances. The pH of } \\
\text { the soil is important for the } \\
\text { availability of lead from its } \\
\text { compounds. } \\
\text { - Lead is quite immobile (e.g. } \\
\text { more than cadmium), it remains } \\
\text { in the topsoil and is not } \\
\text { absorbed by plants to the same } \\
\text { extent. } \\
\text { - Soils thus represent an } \\
\text { important sink for lead } \\
\text { compounds }\end{array}$ \\
\hline 2 & $\begin{array}{l}\text { Cadmium } \\
(\mathrm{Cd})\end{array}$ & $\begin{array}{l}\text { Cadmium is stable in air } \\
\text { since it forms an oxide layer. }\end{array}$ & $\begin{array}{l}\text { - 2/3 - 3/4 of the cadmium in surface water and } \\
\text { groundwater is adsorbed on suspended matter. } \\
\text { It can be remobilised from sediment by } \\
\text { complexing agents. } \\
\text { - Fish toxicity is dependent amongst other things } \\
\text { on the calcium content of the water }\end{array}$ & \\
\hline 3 & Mercury (Hg) & $\begin{array}{l}\text { Washed out more or less } \\
\text { completely by precipitations. }\end{array}$ & $\begin{array}{l}\text { - inhibits the metabolic activity of microorganisms } \\
\text { in water } \\
\text { - Suppresses the self-purification capability of } \\
\text { water at concentrations as low as } 18 \mathrm{~m} \text { g/l. } \\
\text { - Adsorbed on sediment and suspended matter. }\end{array}$ & \\
\hline 4 & $\begin{array}{l}\text { Hexavalent } \\
\text { Chromium }\end{array}$ & & $\begin{array}{l}\text { The toxicity of soluble chromium compounds in } \\
\text { aquatic systems varies depending on the } \\
\text { temperature, } \mathrm{pH} \text { and water hardness as well as on } \\
\text { the species of the organism. Chromium(VI) } \\
\text { compounds are readily } \\
\text { - soluble in water, but are readily reduced under } \\
\text { natural conditions in the presence of organic, } \\
\text { oxidisable material to form less water-soluble, } \\
\text { stable chromium(III) compounds. }\end{array}$ & \\
\hline 5 & $\begin{array}{l}\text { PVC(Polyviny } \\
1 \text { Chloride } \\
\text { Plastics) }\end{array}$ & $\begin{array}{l}\text { On expansion, the } \\
\text { pressurized gas forms cold } \\
\text { mists which are denser than } \\
\text { air. } \\
\text { Evaporates easily and form } \\
\text { toxic, explosive mixtures. }\end{array}$ & $\begin{array}{l}\text { - Persistent in water, if not evaporating. } \\
\text { - there are no known cases of damage to aquatic } \\
\text { organisms } \\
\text { - Accumulation in the aquatic food chain is } \\
\text { unlikely }\end{array}$ & \\
\hline 6 & $\begin{array}{l}\text { Brominated } \\
\text { Flame } \\
\text { Retardants }\end{array}$ & $\begin{array}{l}\text { The liquid readily evaporates } \\
\text { and forms caustic vapours. }\end{array}$ & $\begin{array}{l}\text { - Bromine is denser than water, but dissolves } \\
\text { slightly in water and colours it brown. } \\
\text { - There is a strong hazard to all types of water, in } \\
\text { particular to drinking water, service water and } \\
\text { waste water on account of the high toxicity } \\
\text { linked to oxidising and corrosive properties }\end{array}$ & \\
\hline
\end{tabular}

An innovative trend on sustainability in WEEE management has incorporated the application of frontiers like organic field effect transistors (OFETs) Technology, Organic thin-film transistors (OTFTs), organic light emitting diodes (OLEDs), and organic photovoltaics (OPVs) in the manufacturing of EEE (Okorhi et al., 2015b). Therefore paving ways for technologies of biodegradable materials as suitable products to hitherto inorganic components in EEE manufacturing. According to a report published by Schluep, Hagelueken, Kuehr, Magalini, Maurer, Meskers, Mueller, and Wang (2009), sustainable innovation refers to the shift of sustainable technologies, products and services to the marketplace, requiring a market creation concept and a shared global agenda. Whereas, environmental management and sustainability focuses on findings solutions to global pressing environmental problems. 
It is said that the best available environmentally sound management (ESM) systems are programmes and techniques that produces sustainable environment through its protection, paving way for safer health and working conditions, generating employment as well as other socio-economic benefits (Okorhi, 2015). In pursuit of these, there arises the deployment of frontier strategies (including the 5Rs) for e-waste management. However, the activities of metal recyclers in Nigeria are only indirectly linked to the e-waste recycling sector, as the business outputs are functioning products rather than raw materials (Basel Convention, 2011a).

Table 5: Empirical Data to support Table 3 and 4

\begin{tabular}{|c|c|c|}
\hline $\mathbf{S} / \mathbf{N}$ & COMPONENT & DATA \\
\hline 1 & Lead $(\mathrm{Pb})$ & $\begin{array}{l}\text { In Germany, lead is listed in pregnancy group B (risk of embryonic damage is assumed). } \\
\text { Symptoms of chronic poisoning are lead deposits along the edge of the gums as well as colic } \\
\text { fits and spasms. Apathy, irritability, insomnia and - in some cases - behavioural irregularities in } \\
\text { children are indications of damage to the nervous system. Lead passes through the placenta and } \\
\text { accumulates in the foetus. In Germany, lead is listed in pregnancy group B (risk of embryonic } \\
\text { damage is assumed). }\end{array}$ \\
\hline 2 & Cadmium (Cd) & $\begin{array}{l}\text { In Asia, "Itai-Itai" disease is caused by high cadmium concentrations in rice. Twelve patients } \\
\text { with Itai-Itai disease, thought to be caused by chronic cadmium poisoning (Ishizaki, A: Asian } \\
\text { Med. J. 14:421-436, 1971), showed chromatid aberrations. }\end{array}$ \\
\hline 3 & Mercury (Hg) & $\begin{array}{l}\text { Responsible for the Minamata Bay Disease of Japan in } 1962 \text {. Released Mercury chloride } \\
\text { bioaccumulated in shellfish and fish in Minamata Bay and the Shiranui Sea, which, when eaten } \\
\text { by the local populace, resulted in mercury poisoning. While cat, dog, pig, and human deaths } \\
\text { continued for } 36 \text { years, the government and company did little to prevent the pollution. The } \\
\text { animal effects were severe enough in cats that they came to be called "dancing cat fever". }\end{array}$ \\
\hline 4 & Hexavalent Chromium & $\begin{array}{l}\text { The carcinogenic effect of chromium (VI) compounds has been substantiated both in animal } \\
\text { experiments and by epidemiological studies on groups of population subject to workplace } \\
\text { exposure. The corresponding latency times are given as between } 10 \text { and } 27 \text { years. }\end{array}$ \\
\hline 5 & $\begin{array}{l}\text { PVC(Polyvinyl } \\
\text { Plastics) }\end{array}$ & $\begin{array}{l}\text { The US Congress passed the Safe Drinking Water Act. This law requires EPA to determine the } \\
\text { level of contaminants in drinking water at which no adverse health effects are likely to occur. } \\
\text { These non-enforceable health goals, based solely on possible health risks and exposure over a } \\
\text { lifetime with an adequate margin of safety, are called maximum contaminant level goals } \\
\text { (MCLG). Contaminants are any physical, chemical, biological or radiological substances or } \\
\text { matter in water. }\end{array}$ \\
\hline 6 & Brominated Flame Retardants & $\begin{array}{l}\text { Due to the Michigan accident in 1973-1974, many toxicity studies on PBBs are available. Soil } \\
\text { samples from a former PBB manufacturing site, analysed several years after the Michigan } \\
\text { incident, still contained PBBs though the PBB congener composition was different, indicating a } \\
\text { partial degradation of the PBB residues in the soil sample. Increased levels of polychlorinated } \\
\text { biphenyls (PCBs) and polybrominated diphenyl ethers (PBDEs) were found in breast milk } \\
\text { samples in Accra, Ghana. }\end{array}$ \\
\hline
\end{tabular}

Adapted from the GFMECD (1995) Handbook and NESREA (2009)

Nevertheless, the 2011 Basel Report found the sector producing significant amount of e-waste. This is because the e-waste recycling sector in Nigeria is dominated by firms (or individuals) with "informal" arrangements which collect WEEE at random, manually dismantling (or sorting), preprocessing, selling of valuable components and, dispose of the leftovers (Okorhi, 2015). For instance, precious metals contained in printed wiring boards (PWBs) are rarely collected and when they are, are sold below world market prices to traders that organize exports to Asian recycling facilities (Basel Convention, 2011a). Also, some devices extracted from WEEE are then used as spare parts in the repairs of faulty EEE.

Obviously, the ease to getting vital production materials used in the manufacture of new EEE is gradually drawing fear as world reserves of raw materials is quickly reducing and getting more expensive (Ongodo and William, 2011). The overall aim for "formal" e-waste recycling is to avert hazardous materials from WEEE in an ESM manner; recover prized items as much as possible; build an eco-friendly and sustainable SMEs and; consider the socio-economic implications (Schluep et al., 2009). For a better consideration of the procedure for selecting innovative e-waste recycling technologies in developing countries, Schluep et al. (2009) suggested, among others, the importance of sustainability benchmarks. Table 6 shows the sustainability benchmarks for evaluating and adopting technologies for e-waste recycling in developing countries, including Nigeria. The criteria to compare the innovation of technologies was then grouped along the elements of sustainability. Whereas Table 7 shows some innovative e-waste recycling technologies that could be adopted by ewaste recycling firms in Nigeria. To sum up, the market potential for e-waste recycling are enormous as the annual growth rate of WEEE in Nigeria is put at $10 \%$ in the volume of waste generated (Ayodeji, 2011). It has been identified that a mid-term medium potential for integrated e-waste smelting already exist 
in some countries of Asia, Africa, South and North America (Schluep et al., 2009). Hence, from job creation, entrepreneurship and sustainability viewpoints, the "informal" practices of collection and manually dismantling of e-waste may not really require a transformation to a "formal" arrangement using high-tech equipment for the processing of WEEE (Rochat and Rodrigues, 2008). The innovative technologies been continuously adapted by the larger informal sector in Nigeria is now gaining ground (Basel Convention, 2011a). Opportunities in recycling of e-waste arises in the improvement of the processing of cable-coated from poly-vinyl-chloride and insulators, and polybrominated biphenyls coated plastics. Also is the collection of large quantities of PWBs for export and fair pricing. By using the voluntary carbon standard (VCS) or carbon action reserve (CAR) schemes, there is now the potential of recovering chlorofluorocarbon from cooling units and insulation foam which in turn brings both environmental and economic gains (Basel Convention, 2011a). It was also suggested that the improved utilization of polystyrene from e-waste recycling would guarantee a higher monetary value from the pricing of carbon (IV) oxide.

Table 6: Sustainability Benchmarks for Evaluating and Adopting Technologies for E-Waste Recycling In Developing Countries (Schluep et

\begin{tabular}{|c|c|c|c|c|}
\hline \multicolumn{2}{|l|}{ Attributes } & \multicolumn{3}{|l|}{ Indicators involved } \\
\hline \multicolumn{5}{|l|}{ Economic attributes } \\
\hline \multicolumn{2}{|l|}{ Low net costs } & \multicolumn{3}{|c|}{ Costs for transport, processing and labour vs. revenues } \\
\hline \multicolumn{2}{|l|}{ Low capital costs } & \multicolumn{3}{|c|}{ Investment costs for additional plants and technologies used in a scenario } \\
\hline \multicolumn{2}{|c|}{$\begin{array}{l}\text { Increased potential for local economic growth } \\
\text { Environmental attributes }\end{array}$} & \multicolumn{3}{|c|}{ Additional industries and services involved by implementing a scenario } \\
\hline \multicolumn{2}{|l|}{ Low use of electricity } & \multicolumn{3}{|c|}{ Savings of electricity but also energy in general by implementing a scenario } \\
\hline \multicolumn{2}{|c|}{ Low fuel use for transport } & \multicolumn{3}{|c|}{ Fuel used by shipping and road transport } \\
\hline \multicolumn{2}{|l|}{ Low use of freshwater } & \multicolumn{3}{|c|}{ Freshwater consumption of a recycling scenario } \\
\hline \multicolumn{2}{|l|}{ Little (toxic) emissions } & \multicolumn{3}{|c|}{$\begin{array}{l}\text { Caused vs. prevented emissions according to the savings of raw materials } \\
\text { calculated with eco-indicator ' } 99 \text { (or other appropriate tools) }\end{array}$} \\
\hline \multicolumn{2}{|c|}{ High metal recovery rates } & \multicolumn{3}{|c|}{$\begin{array}{l}\text { Range and yields of metals contained in the waste, which can be recovered and } \\
\text { used as secondary raw material. In case of technical conflicts prioritization by } \\
\text { economic and environmental value ("footprint") of the recovered substances. }\end{array}$} \\
\hline \multicolumn{5}{|l|}{ Social attributes } \\
\hline \multicolumn{2}{|c|}{$\begin{array}{l}\text { Creation of jobs for the previously } \\
\text { unemployed }\end{array}$} & \multicolumn{3}{|c|}{ Working hours for low-skilled and semi-skilled workers generated } \\
\hline \multicolumn{2}{|c|}{ Creation of highly skilled jobs } & \multicolumn{3}{|c|}{ Working hours for highly skilled workers generated } \\
\hline \multicolumn{2}{|c|}{ Creation of jobs outside the target country } & \multicolumn{3}{|c|}{ Working hours generated outside the target country } \\
\hline \multicolumn{2}{|c|}{ Low health and safety impacts } & \multicolumn{3}{|c|}{$\begin{array}{l}\text { Impacts of a scenario on health and safety of the employees engaged in a } \\
\text { scenario }\end{array}$} \\
\hline \multicolumn{5}{|c|}{ Table 7: Innovative E-Waste Recycling Technologies for Recycling Firms (Schluep et al., 2009) } \\
\hline & Waste streams & Economic attributes & $\begin{array}{l}\text { Environmental } \\
\text { attributes }\end{array}$ & Social attributes \\
\hline $\begin{array}{l}\text { Manual dismantling/ } \\
\text { sorting of fractions }\end{array}$ & All & $\begin{array}{l}\text { Low capital cost, sorting of valuable } \\
\text { fractions/ components }\end{array}$ & $\begin{array}{l}\text { Efficient sorting of } \\
\text { fractions }\end{array}$ & $\begin{array}{l}\text { Labour intensive, Job } \\
\text { creation }\end{array}$ \\
\hline De-gassing CFC, HCFC & $C \& F$ & $\begin{array}{l}\text { Mandatory requirement having low } \\
\text { cost }\end{array}$ & $\begin{array}{l}\text { Fundamental step to } \\
\text { ensure control over } \\
\text { hazardous substances } \\
\text { having huge GWP } \\
\text { potential }\end{array}$ & \\
\hline $\begin{array}{l}\text { Semi-automatic CRT } \\
\text { cut and cleaning }\end{array}$ & CRT & $\begin{array}{l}\text { Low capital and net } \\
\text { Cost }\end{array}$ & $\begin{array}{l}\text { Low energy } \\
\text { consumption }\end{array}$ & Labour intensive \\
\hline $\begin{array}{l}\text { Integrated smelter for } \\
\text { non-ferrous } \\
\text { (pyrometallurgical } \\
\text { methods) }\end{array}$ & $\begin{array}{l}\text { Non-ferrous } \\
\text { (including printed } \\
\text { wiring boards) like } \\
\mathrm{Cu}, \mathrm{Pb}, \mathrm{Zn}, \mathrm{Sn} \text { or } \\
\text { mix }\end{array}$ & $\begin{array}{l}\text { Capital cost high } \\
\text { Low net (unit) costs } \\
\text { due to economies of } \\
\text { scale } \\
\text { Local growth potential } \\
\text { High }\end{array}$ & $\begin{array}{l}\text { No toxic emissions } \\
\text { Low water use } \\
\text { Transport: } \\
\text { internationally } \\
\text { Little waste products } \\
\text { Recovery rates }>> \\
90 \%\end{array}$ & $\begin{array}{l}\text { Automated process } \\
\text { control so less jobs } \\
\text { created } \\
\text { Highly skilled } \\
\text { workforce } \\
\text { EHS* }\end{array}$ \\
\hline $\begin{array}{l}\text { Aluminium } \\
\text { remelter/refiner }\end{array}$ & Aluminium & $\begin{array}{l}\text { Captial cost medium - } \\
\text { high } \\
\text { Net cost low } \\
\text { Economies of scale }\end{array}$ & $\begin{array}{l}\text { No toxic emissions } \\
\text { Salt slag has to be } \\
\text { treated or disposed } \\
\text { Env. sound } \\
\text { Transport within } \\
\text { region or country } \\
\text { Water use: low - } \\
\text { medium }\end{array}$ & $\begin{array}{l}\text { Job creation: yes } \\
\text { Mix of low skilled } \\
\text { and high skilled } \\
\text { jobs } \\
\text { EHS low risks }\end{array}$ \\
\hline
\end{tabular}


The Bamako Convention had emphasized the need for urgent introduction and enforcement of policies at all arms of government dealing specifically with WEEE streams. This review has identified the sources of WEEE, its characterization and frontline technologies in managing the WEEE problem through recycling. Proposed recycling frontiers should be adopted in line with elements of sustainability and market potentials. Specifically, legislations should reflect more on potentials for recycling thereby promoting conservation, entrepreneurship and job creation.

\section{REFERENCES}

Agency for Toxic Substances and Disease Registry, ATSDR, (2017). Managing Hazardous Materials Incidents (MHMIs). U.S. Department of Health and Human Services Public Health Service Agency for Toxic Substances and Disease Registry. Viewed on 6 November, 2017. Available at: https://www.atsdr.cdc.gov/

Alo B. I. (2009). Best Available Environmentally Sound Management Practices In E-Waste Control. In proceedings of the International Conference on E-Waste Control Abuja, Nigeria: The Abuja Platform on E-Waste. Abuja: National Environmental Standards and Regulations Enforcement Agency (NESREA).

Ayodeji Odeyingbo Olusegun (2011). Assessment of the flow and driving forces of used electrical and electronic equipment into and within Nigeria. Master Thesis. Environmental and Resource Management. BTU Cottbus, viewed 21, January, 2013, isp.unu.edu/publications/scycle/files/masterthesis-olusegun.pdf. Pp 1-104

Bamako Convention (1991) Decision on the Prevention of Hazardous e-Waste and Near End-of-Life Importation and Dumping in Africa. Viewed 10, December, 2017. Available at http://www.sea.org.sz/documents/Bamako_Conven tion.pdf

Basel Convention (2011a). Where are WEee in Africa? Findings from the Basel Convention. E-waste Africa Programme. Secretariat of the Basel Convention (SBC), viewed 04, January, 2013,<www.basel.int.> pp. 1-50

Basel Convention (2011b). Report of the Conference of the Parties to the Basel Convention on the Control of Transboundary Movements of Hazardous Wastes and Their Disposal on the work of its eleventh meeting, Conference of the Parties to the Basel Convention on the Control of Transboundary Movements of Hazardous Wastes and Their Disposal Eleventh meeting Geneva, 28 April - 10 May 2013, viewed on 20 November, 2013, <
www.basel.int/Portals/4/download.aspx?d=UNEPCHW.11-24...pdf>

BCCC-Nigeria and Empa (2011). UNEP SBC E-waste Africa Project: Building local capacity to address the flow of e-wastes and electrical and electronic products destined for reuse in selected African countries and augment the sustainable management of resources through the recovery of materials in ewastes. In contribution to components 1 and 2 : Nigeria e-Waste Country Assessment. Ibadan/Nigeria and St.Gallen/Switzerland. Retrieved from http://ewasteguide.info/files/Ogungbuyi_2012_BC CC-Empa.pdf.

Davis, G.; Herat, S. (2008). Electronic waste: The local government perspective in Queensland, Australia. Resources, Conservation and Recycling, 52 (8-9), pp. 1031-1039.

Europe Union (2006). Regulation (EC) No 1013/2006 of the European Parliament and of the Council of 14 June 2006 on Shipments of Waste. Official Journal of the European Union. Viewed 13 June, 2015. Retrieved from http://www.eurlex.europa.eu/LexUriServ/ LexUriServ.do.

GFMECD (1995). Environmental Handbook Documentation on Monetary and Evaluating Environmental Impacts. Volume 1. GmbH, Eschborn: Deutsche Gesellschaft fur. Technische zusammenarbeit. Pp. 320 - 391

Ketai H.; Li L.; Wenying D. (2008). Research on recovery logistics network of Waste Electronic and Electrical Equipment in China. In Industrial Electronics and Applications, 2008. ICIEA 2008. 3rd IEEE Conference on Industrial Electronics and Applications, pp. 1797-1802.

National Environmental Standards and Regulations Enforcement Agency, NESREA, (2007). NESREA (Establishment) Act, $2007 \quad$ A635-655.,

Federal Republic of Nigeria Official Gazette N0.92 Lagos - 31st July, 2007, Vol. 94. Lagos: Printed and Published by the Federal Government Printer, Lagos, Nigeria FGP 125/82007/1,000 (0L 90).NESREA, 2011a, The National Environmental (Electrical/Electronic Sector) Regulations S.I. No. 23 of 2011, Federal Republic of Nigeria Official Gazette No. 50 Lagos - 25th May, 2011, The Federal Government Printer, Lagos, Nigeria. FGP75/72011/400(OL47).

NESREA (2009). Abuja Platform on E-Waste: Working Group 1 Report. In proceedings of the International Conference on E-Waste Control Abuja, Nigeria: The Abuja Platform on E-Waste. Abuja: National Environmental Standards and Regulations Enforcement Agency (NESREA). 
NESREA (2011b). Global Perspective of E-Waste: A Keynote Address by Dr. (Mrs) Ngeri S. Benebo Jp., at the

EKO E-waste summit. Retrieved from http://elring.org/DG\%20speech\%20at\%20EKO\% 20Ewaste\%20summit\%2009022011.pdf.

Okorhi O. J.; Amadi-Echendu J. E.; Aderemi H. O.; Otejere J. (2015a). Technology Paradigm for EWaste Management in South-Eastern Nigeria. Proceedings of the 24th International Conference on Management of Technology (IAMOT 2015) holding at The Westin, Cape Town, South Africa. Retrieved

from http://iamot2015.com/2015proceedings/documents/ P099.pdf.

Okorhi O. J.; Amadi-Echendu J. E.; Aderemi H. O. (2015b). Towards Use of Biodegradable Materials as Electro-Components. Proceedings of the 24th International Conference on Management of Technology (IAMOT 2015) holding at The Westin, Cape Town, South Africa. Retrieved from http://iamot2015.com/2015proceedings/documents/ P124.pdf.

Okorhi O. J.; Omotor D. A.; Aderemi H. O.; Abang S. I. (2017). Wastes from Industrialized Countries: A Socio-economic inquiry on Sustainable Management of E-waste for the Recycling Sector in Nigeria. Proceedings of the $3^{\text {rd }}$ AfricaLics International Conference: Emerging Innovation Systems for Sustainable Industrial Development in Africa held between 27 and 29 November, 2017 at the Oran University 2, Oran, Algeria.

Okorhi Ojiyovwi Johnson (2015). Assessment of Waste Electrical and Electronic Equipment Management Strategies in South Eastern Nigeria. Doctoral Thesis, Institute of Engineering, Technology, and Innovation Management, University of Port Harcourt, Nigeria, Page 1-180

Ongondo Francis O.; Williams Ian D. (2011). Are WEEE in Control? Rethinking Strategies for Managing Waste Electrical and Electronic Equipment. Integrated Waste Management Volume II, Mr. Sunil Kumar (Ed.), ISBN: 978-953307-447-4, InTech. Retrieved from http://www.intechopen.com/books/integratedwastemanagement-volume-ii/are-weee-in-controlrethinking-strategies-for-managing-wasteelectrical-andelectronic-equipment. Pp 361 - 380 .

Onyejekwe E. R. (2009). Environmental and Health Impact of E-Waste. In proceedings of the International Conference on E-Waste Control Abuja, Nigeria: The Abuja Platform on E-Waste. Abuja: National Environmental Standards and Regulations Enforcement Agency (NESREA).
Oresanya Ola, (2011). E-Waste Management in Lagos State: The LAWMA experience. Paper presented at the 2-Day International Summit on Regulations and Management of e-Waste in Nigeria (Eko e-Waste Summit), viewed 12 January, 2013, < www.lawma.gov.ng>

Osibanjo, O; Nnorom, I.C. (2008). Electronic waste (ewaste): Material flows and management practises in Nigeria. ELSEVIER. Waste Management 28 (2008), viewed 21, January, 2013, $<$ www.elsevier.com/locate/wasman> $<$ www.sciencedirect.com> pp. 1472-1479

Puckett, J.; Byster, L.; Westervelt, S.; Gutierrez, R.; Davis, S.; Hussain, A.; Dutta, M. (2003). Exporting Harm: The High-Tech Trashing of Asia. Basel Action Network and Silicon Recycling. Switzerland: Secretariat of the Basel Convention (SBC). 44 (1), pp. 17-35.

Rochat D.; Rodrigues W., et al. (2008). India: Including the Existing Informal Sector in a Clean e-Waste Channel. In: Proceedings of the Waste Management Conference (WasteCon2008), Durban, South Africa.

Schluep, M.; Hagelueken, C.; Kuehr, R.; Magalini, F.; Maurer, C.; Meskers, C.; Mueller, E.; Wang, F. (2009). Recycling - from e-waste to resources, Sustainable innovation and technology transfer industrial sector studies. Paris, France: Empa, Umicore, UNU.

StEP (2011). StEP Annual Report 2010. StEP, Secretariat c/o United Nations University Institute for Sustainability and Peace (UNU-ISP), Germany, viewed $26 \quad$ November, $2012<$ www.ehs.unu.edu/file/get/8661>

The Guardian (2012). Domestic consumption Fuels: Africa's e-waste imports, says report. The Environment. The Guardian, Monday, February 13, 2012. Pp. 48-49.

$<$ www.ngrguardiannews.com $>$. [Last accessed 13, February, 2012]

Vanguard (2013). FG orders return of toxic ship to UK. Vanguard On-line News: 12th January, 2013, viewed 13, February, 2013, http://www.vanguardngr.com/2013/01/toxic-wastefg-to-sanction-ship-owners 